\title{
The 2002 Canadian Thoracic Society meeting
}

$\mathrm{T}$ his issue of the Canadian Respiratory Journal contains summaries of papers presented at the meeting of the Canadian Thoracic Society (CTS) in the fall of 2002, and reviewing them led me to think about the history of this meeting, at least insofar as my experience, which amounts to about 40 years. I recognize that this kind of nostalgia is not everyone's cup of tea - especially if one is younger than I am, and almost everyone is, but I'm the guy who's supposed to write the editorial.

The CTS was founded in the mid-1950s. It has always been the medical wing of the Canadian Lung Association, but when I arrived on the scene in the mid-1960s, the latter was the Canadian Tuberculosis and Lung Disease Association. It was really concerned with tuberculosis (TB), as was the membership of the CTS, to a large extent. In those days, academic medicine and teaching hospitals had variable and sometimes tenuous relationships with the TB establishment, including its physicians. Canadian academic pulmonary medicine was entering its glory years; enormous amounts of original clinical and physiological research were being done in a number of world-class Canadian institutions. One of the most charismatic and concerned pulmonary academics was Reuben Cherniack of Winnipeg, Manitoba. He strongly promoted the involvement of the academic pulmonary community in the CTS and its mother institution. Academics joined the CTS in large numbers and took over its meetings to a major extent. The TB establishment's reaction was not one of unalloyed joy, but it also recognized the advantages that came with an influx of youth, energy and enthusiasm.

The CTS had its own meeting in association with the lay organization; it was held in June at a wide variety of venues, including Moncton and Saskatoon. Abstracts were submitted and presented; presentations consisted of 10 min of slides and 5 min of discussion. The academic community submitted the abstracts and attended the meeting, which lasted several days. From the late 1960s to the early 1980s, this was the rule. In those days, the American Thoracic Society (ATS) meeting was much smaller than it is now and was of no better quality than that of the CTS. Airfares and hotel costs were such that one could attend a couple of American and a couple of Canadian meetings per year. I regularly went to the meetings for the CTS, the Canadian Society for Clinical Investigation (CSCI), the American Physiological Society and the ATS, took some fellows and paid for most of it with research grants! Sometimes, to be perfectly honest, I presented the same or similar abstracts at more than one of them. Canadian meetings, including those of the CTS, were scientifically good, and had the additional advantage of being informal reunions with colleagues and ex-colleagues. There were splendid social events, featuring local specialties such as barbecued food and lobster.

\section{Le congrès de la Société
adienne de thoracologie \\ Le congrès de la Société
canadienne de thoracologie}

I e présent numéro du Canadian Respiratory LJournal contient des résumés d'articles présentés au congrès de la Société canadienne de thoracologie (SCT) de l'automne 2002. En les révisant, je me suis mis à penser à l'historique de ce congrès, du moins pour ce qui est de mon expérience personnelle, qui remonte à il y a une quarantaine d'années. J'admets que ce type de nostalgie n'a pas l'heur de plaire à tous, surtout à ceux qui sont plus jeunes que moi, et presque tout le monde l'est, mais c'est moi qui dois rédiger l'éditorial.

La SCT a été fondée au milieu des années 1950. Elle a toujours représenté l'aile médicale de l'Association pulmonaire du Canada, mais lorsque je suis arrivé au milieu des années 1960, cette association s'appelait Association canadienne contre la tuberculose et les maladies respiratoires. En réalité, elle s'intéressait à la tuberculose (TB), tout comme la plupart des membres de la SCT. À cette époque, la médecine universitaire et les hôpitaux d'enseignement avaient des relations variables et parfois ténues avec le milieu de la TB, y compris ses médecins. La médecine pulmonaire universitaire canadienne amorçait ses années de gloire. Une quantité considérable de recherches cliniques et physiologiques originales était menée dans plusieurs établissements canadiens d'envergure internationale. Reuben Cherniak, de Winnipeg, au Manitoba, était l'un des universitaires du milieu pulmonaire les plus charismatiques et les plus intéressés. Il a fait une promotion énergique de la participation de la collectivité pulmonaire universitaire à la SCT et à son institution mère. Les universitaires ont adhéré à la SCT en grand nombre et ont pris le contrôle du congrès dans une vaste mesure. Le milieu de la TB n'a pas réagi par une joie sans mélange, mais il a compris les avantages d'un afflux de jeunesse, d'énergie et d'enthousiasme.

La SCT tenait ses propres congrès en association avec l'organisation profane. Ces congrès avaient lieu en juin, à divers endroits, y compris Moncton et Saskatoon. Des résumés étaient soumis et présentés. Les présentations se composaient de dix minutes de diapositives et de cinq minutes de discussions. La collectivité universitaire soumettait les résumés et assistait au congrès, qui durait plusieurs jours. Entre la fin des années 1960 et le début des années 1980, c'était la règle. À l'époque, le congrès de l'American Thoracic Society (ATS) était beaucoup plus petit qu'il ne l'est maintenant, et n'était pas de meilleure qualité que celui de la SCT. Le prix des billets d'avion et des chambres d'hôtel était tel qu'il était possible d'assister à quelques congrès américains et à quelques congrès canadiens tous les ans. J'assistais régulièrement aux congrès de la SCT, de la Société canadienne de recherches cliniques (SCRC), de l'American Physiological Society et de l'ATS, j'y amenais des collègues et je payais la plupart des frais avec des subventions de recherche! Parfois, pour être parfaitement honnête, je présentais le même résumé ou des résumés similaires à plus d'un con- 
At a Calgary, Alberta meeting, the after-dinner speaker was none other than WO Mitchell! At the time, I had no idea who he was, but I will never forget the event; it probably was the funniest talk I have ever heard.

These halcyon days began to wane in the early 1980s. This was due to the enormous growth of the ATS and rapid escalation of the price of a meeting, largely due, I think, to rising hotel and airfare costs. Attendance at Canadian meetings, including the CTS meetings, started to dwindle. It took some time to reach the point of nonviability, but this eventually occurred. Jim Hogg was the president of CTS at the time, and he essentially organized the demise of the independent meeting. No one was happy, but it was necessary to bow to the inevitable. Jim's solution was to run a CTS meeting as part of the joint meetings of the CSCI and Royal College of Physicians and Surgeons of Canada. The CTS had a couple of half-days at this meeting, with some ceremonial overtones. This arrangement initially worked well, but it also eventually succumbed to the influences that killed the independent CTS meeting. By the mid-1990s, it was not common to meet easterners at a western meeting and vice versa. Though the quality of the meeting remained good, the attendance was not. The CSCI and Royal College settled the fate of the meeting when the consortium decided to drop its scientific program in the late 1990s.

Don Cockcroft was president of the CTS, and was therefore in charge of what to do next. The obvious solution was to run a CTS meeting in conjunction with the ATS meeting, because everyone went to the latter anyway. The ATS declined to permit this, which was a bitter pill, given the fact that it had run two of its meetings in Canada that were billed as joint meetings with the CTS. Canadians were welcome at the ATS meeting, but a segregated CTS program was not. Don did find an organization that was hospitable to the CTS - the American College of Chest Physicians. For the past few years, our meetings have been held together with theirs. This arrangement has plenty of detractors, but those who don't like it have yet to produce a better idea.

In any event, the bulk of this issue of the Canadian Respiratory Journal is made up of papers from the most recent of these meetings. I congratulate the organizers. The topics are excellent, and the authors are typical of the best that we have to offer. Most amazing, perhaps, is the fact that Darcy Marciniuk was able to extract concise and interesting summaries from the speakers in such a short time. It looks like it was a splendid meeting. I confess that I wasn't there, and I'm feeling very guilty.

Nick R Anthonisen MD Editor-in-Chief

Canadian Respiratory Journal grès. Les congrès canadiens, y compris ceux de la SCT, étaient bons d'un point de vue scientifique, et comportaient l'avantage supplémentaire de constituer des rencontres amicales avec des collègues ou d'anciens collègues. C'était de splendides réunions sociales, comportant des spécialités locales comme les grillades et le homard. À un congrès de Calgary, en Alberta, le conférencier qui suivait le banquet n'était nul autre que WO Mitchell ! À l'époque, je n'avais aucune idée de qui il était, mais je n'oublierai jamais cette soirée. C'est probablement l'allocution la plus drôle que j'aie jamais entendue !

Cette période enchanteresse a commencé à s'estomper au début des années 1980, en raison de la croissance énorme de l'ATS et de l'escalade rapide du coût des congrès, causée en grande partie, à mon avis, par le prix des billets d'avion et des chambres d'hôtel. La participation aux congrès canadiens, y compris ceux de la SCT, a commencé à diminuer. Il a fallu un certain temps avant d'atteindre le point de non-viabilité, qui a tout de même fini par se produire. John Hogg était alors président de la SCT, et il a en grande partie organisé le démantèlement du congrès indépendant. Personne n'en était heureux, mais il fallait se rendre à l'évidence. La solution de Jim fut de tenir un congrès de la SCT dans le cadre du congrès conjoint de la SCRC et du Collège royal des médecins et chirurgiens du Canada. La SCT organisait quelques demi-journées et quelques cérémonies de ce congrès. Au départ, ces dispositions ont bien fonctionné, mais elles ont fini par succomber aux influences qui avaient présidé à la disparition du congrès indépendant de la SCT. Au milieu des années 1990, il n'était pas courant de rencontrer des habitants de la côte Est aux congrès de la côte Ouest, et vice-versa. La qualité du congrès demeurait élevée, mais pas la participation. La SCRC et le Collège royal ont réglé le sort du congrès lorsque le consortium a décidé de laisser tomber son programme scientifique à la fin des années 1990.

Don Cockroft présidait alors la SCT, et il fut donc chargé de ce qui se produirait ensuite. La solution évidente était de tenir un congrès de la SCT en même temps que le congrès de l'ATS, auquel tout le monde assistait déjà de toute façon. L'ATS a refusé, et ce fut difficile à avaler, puisque l'organisation avait déjà tenu deux congrès au Canada qui avaient été qualifiés de congrès conjoints avec la SCT. Les Canadiens étaient bienvenus au congrès de l'ATS, mais un programme spécial de la SCT ne l'était pas. Don a toutefois trouvé une organisation prête à accueillir la SCT, l'American College of Chest Physicians. Depuis les quelques dernières années, nous tenons nos congrès ensemble. Ces dispositions comptent beaucoup de détracteurs, mais ceux-ci n'ont pas encore proposé de meilleure idée.

Quoi qu'il en soit, la majeure partie du présent numéro du Canadian Respiratory Journal est constituée d'articles tirés du plus récent de ces congrès. Je félicite les organisateurs. Les sujets étaient excellents, et les auteurs sont représentatifs des meilleurs que nous puissions offrir. Ce qui est peut-être le plus surprenant, c'est que Darcy Marciniuk ait pu obtenir des résumés concis et intéressants des conférenciers en un laps de temps si court. Le congrès semble avoir été splendide. J'avoue ne pas y avoir assisté, et je me sens très coupable de l'avoir raté.

Nick R Anthonisen, M.D. Rédacteur en chef

Canadian Respiratory Journal 


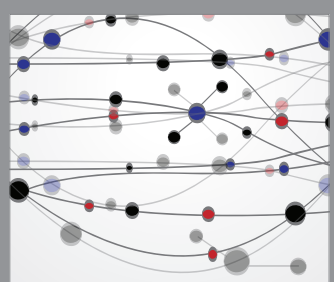

The Scientific World Journal
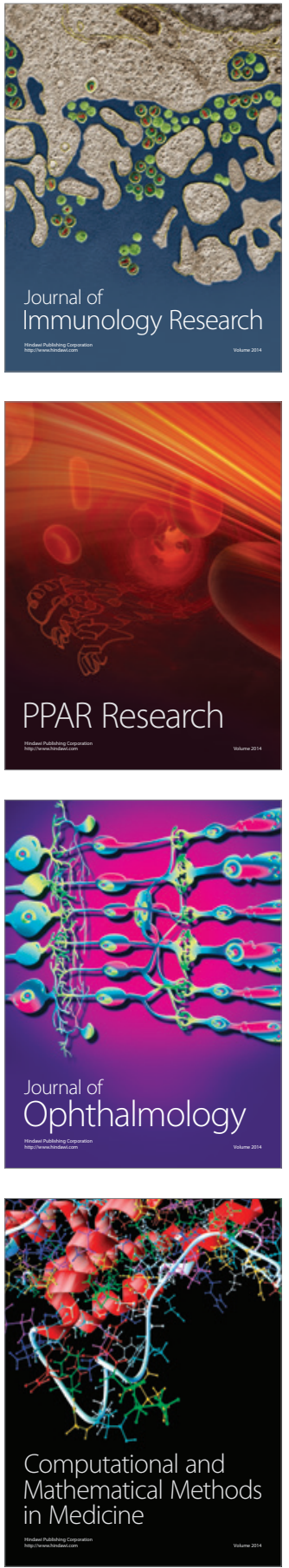

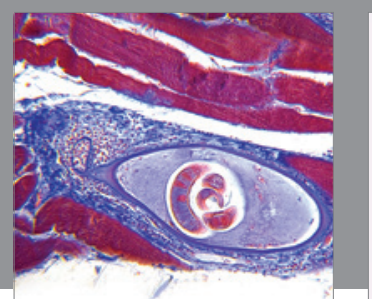

Gastroenterology Research and Practice

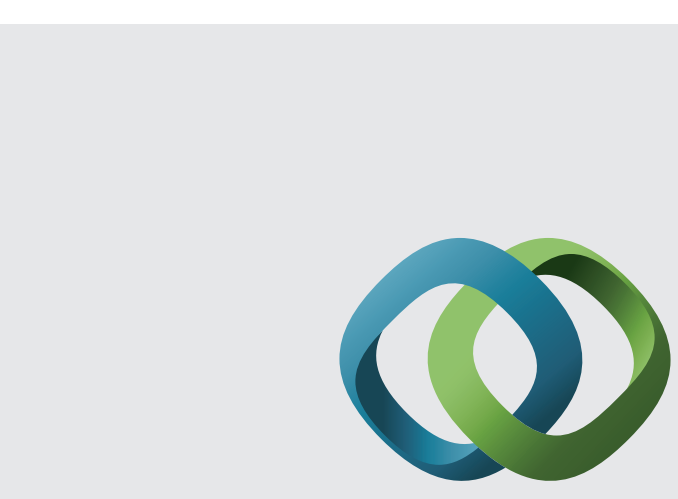

\section{Hindawi}

Submit your manuscripts at

http://www.hindawi.com
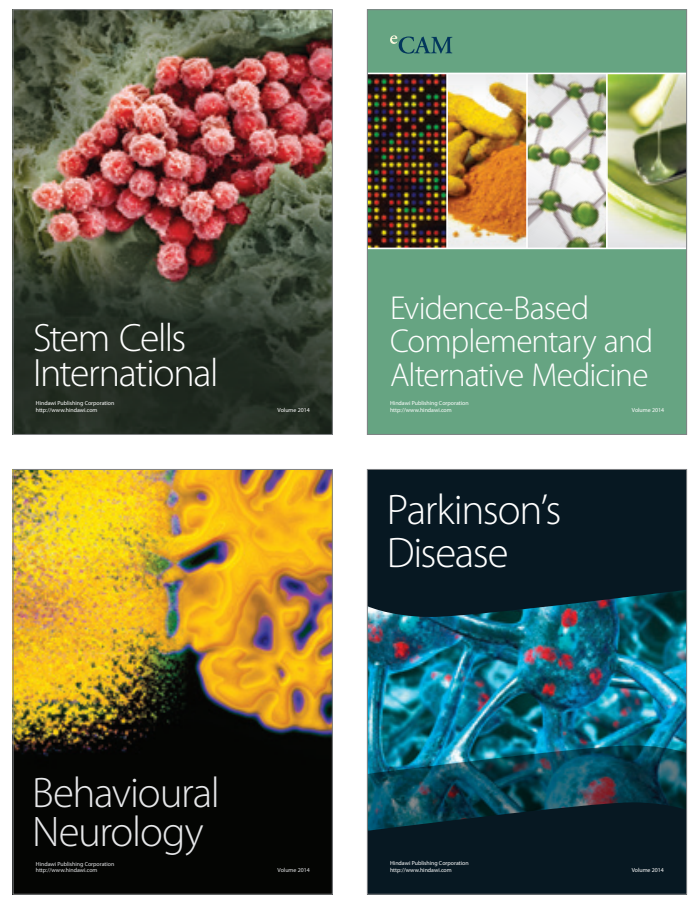
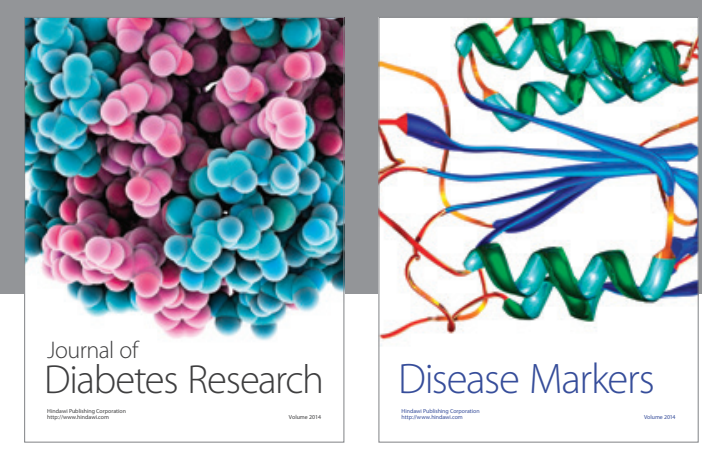

Disease Markers
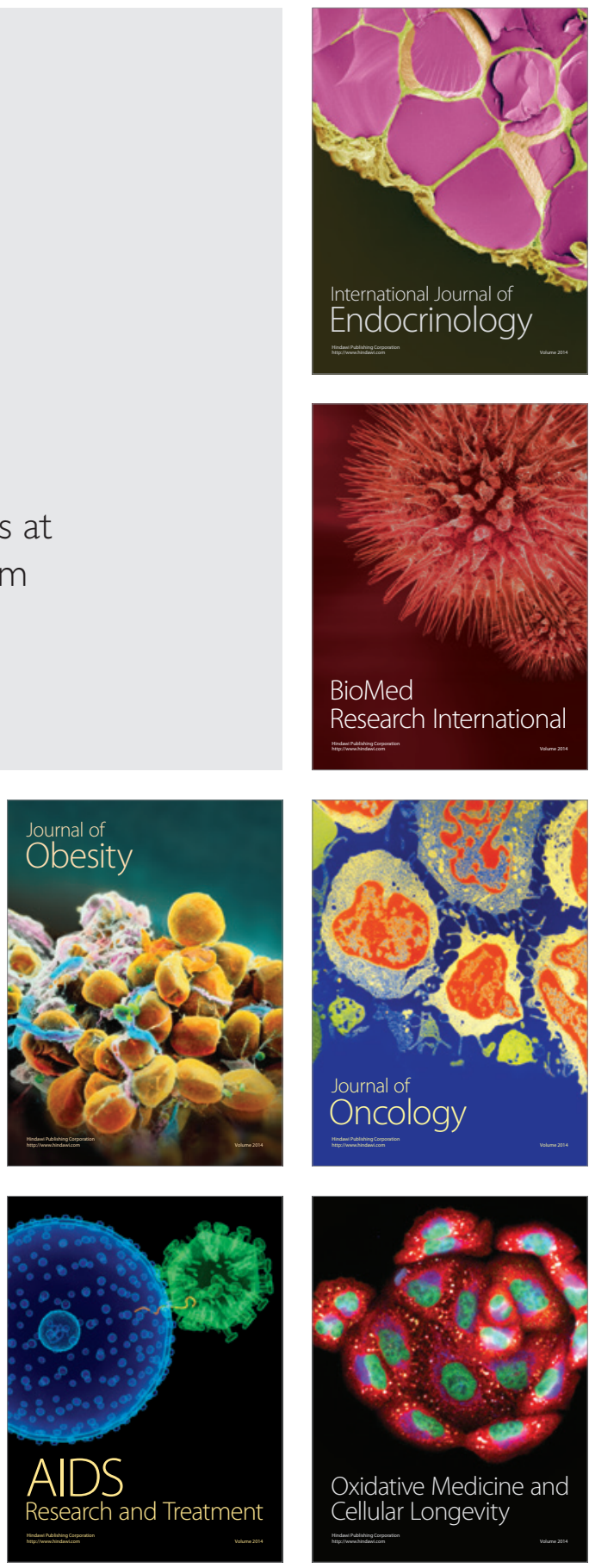